\title{
Arvelig tarmkreft og annen kreft
}

\author{
Lynchs syndrom gir økt risiko for livmorkreft, prostatakreft og egg- \\ stokkreft. Testing av svulstvev fra pasienter med disse kreftformene \\ kan identifisere flere risikopersoner.
}

Lynchs syndrom eller hereditær ikkepolypøs kolorektalcancer er det vanligste arvelige tarmkreftsyndromet. Det skyldes en nedarvet genfeil i ett av fire reparasjonsgener. Lynchs syndrom gir også økt risiko for annen type kreft. Eli Marie Grindedal har studert forekomst av livmorkreft, eggstokkreft og prostatakreft ved Lynchs syndrom og beregnet kliniske kriteriers sensitivitet for å påvise familier med gen-

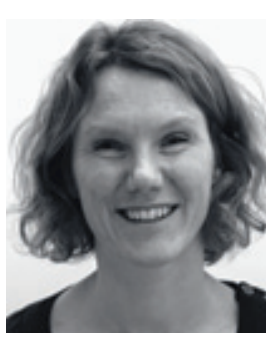

Eli Marie Grindedal. Foto Stefan Magnus Landrø feil. Avhandlingen Extra-colonic cancers in Lynch Syndrom viser at den økte risikoen for livmorkreft er begrenset til familier hvor det blir påvist genfeil, og at Lynchs syndrom gir økt risiko for prostatakreft. Studien viste også at egg- stokkreft forbundet med Lynchs syndrom innebærer høyere overlevelse enn sporadisk eggstokkreft.

- De kliniske kriteriene er ikke sensitive nok til å identifisere familier med genfeil. Gentesting basert på opphoping av kreft i familier er derfor ikke tilstrekkelig for å oppdage alle mutasjonsbærere. Immunhistokjemisk testing og testing for mikrosatellittinstabilitet i svulstvev fra alle pasienter med livmorkreft, eggstokkreft og prostatakreft kan bidra til å identifisere flere familier og friske familiemedlemmer med Lynchs syndrom. Dette er viktig for å kunne tilby dem et kontrollopplegg, slik at kreft kan diagnostiseres tidlig og eventuelt forebygges, sier Grindedal.

\section{Anne Forus}

anneforus@hotmail.com

Tidsskriftet
Doktoravhandlinger

Se oversikt på side 315

Tips oss om spennend

doktoravhandlinger

wWw.tidsskriftet.no/doktoravhandlinger

\section{Doktorgradsinformasjon}

Eli Marie Grindedal disputerte for ph.d.graden ved Universitetet i Bergen 12.11. 2010.

\section{Ordforklaringer}

Reparasjonsgener: Gener som koder for proteiner som reparerer feil i som oppstår under DNA-replikasjon. Lynchs syndrom forårsakes av genfeil i ett av de fire genene MLH1, MSH2, MSH6 eller PMS2.

Penetrans: Andelen individer med sykdomsgivende genfeil som blir syke.

Mikrosatellittinstabilitet: Endringer i repeterte DNA-sekvenser kalt mikrosatellitter. Mikrosatellitter er følsomme for replikasjonsfeil, og mikrosatellittinstabilitet er et kjennetegn på svulster forårsaket av genfeil i reparasjonsgenene.

\section{Risiko for plutselig hjertedød}

\author{
En ny, ultralydbasert metode kan avsløre risiko for plutselig hjertedød \\ hos personer som har hatt hjerteinfarkt eller har arvelig hjerterytme- \\ forstyrrelse, lang QT-syndrom.
}

Plutselig hjertedød pga. hjerterytmeforstyrrelser er en av de vanligste dødsårsakene utgjør den største risikogruppen. Plutselig hjertedød hos yngre skyldes ofte arvelige hjertesykdommer, som f.eks. lang QT-syndrom (LQTS). Risikopersoner kan få forebyggende medikamentell behandling, og de med høy risiko kan få operert inn hjertestarter. Kristina Hermann Haugaa viser i avhandlingen Prediction of cardiac venin patients at risk at en ny, ultralydbasert metode kan avsløre hvem som har risiko for hjerterytmeforstyrrelse og hvem som ikke har det. Dette kan gi et bedre behandlingstilbud til pasientgruppen.

- Vi undersøkte 101 personer med påvist mutasjon i et av LQTS-genene. Halvparten i Norge. De som har hatt hjerteinfarkt, tricular arrhythmias by echocardiography hadde hatt symptomer, halvparten var asymptomatiske. Vi undersøkte også over 80 pasienter som hadde hatt hjerteinfarkt. Disse ble fulgt $i$ to år etter infarktet. Vi viste at ujevn hjertekontraksjon er en risikomarkør for hjerterytmeforstyrrelse og at vår ultralydbaserte metode måler dette bedre enn de metodene som brukes i klinisk arbeid i dag. Bedre risikovurdering kan gi bedre utvelgelse av pasienter med høy dødsrisiko, slik at de kan utstyres med automatisk hjertestarter, sier Haugaa.

\section{Anne Forus}

anneforus@hotmail.com

Tidsskriftet

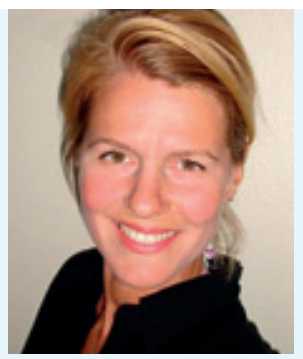

Kristina Hermann Haugaa. Foto privat

\section{Doktorgradsinformasjon}

Kristina Hermann Haugaa disputerte for ph.d.-graden ved Universitetet i Oslo 14.12 2010.

\section{Ordforklaringer}

LQTS: Lang QT-syndrom er en arvelig hjerterytmeforstyrrelse som kan skyldes mutasjon i flere ulike gener. Personer med mutasjon i ett av disse genene har økt risiko for hjerterytmeforstyrrelser som kan medføre plutselig hjertedød.

Ultralydbasert metode: Den nye metoden er basert på vevsdopplerundersøkelser og strainekkokardiografi. Disse metodene gir mulighet for nøyaktig å bestemme varigheten av hjertekontraksjonen i mange ulike deler av hjertet samtidig. 